HOW TO MAKE $\&$ \& \& \& \& \& 8 IMPROVEMENT $\Leftrightarrow \Leftrightarrow$ THINNINGS IN MASSACHUSETTS WOODLANDS

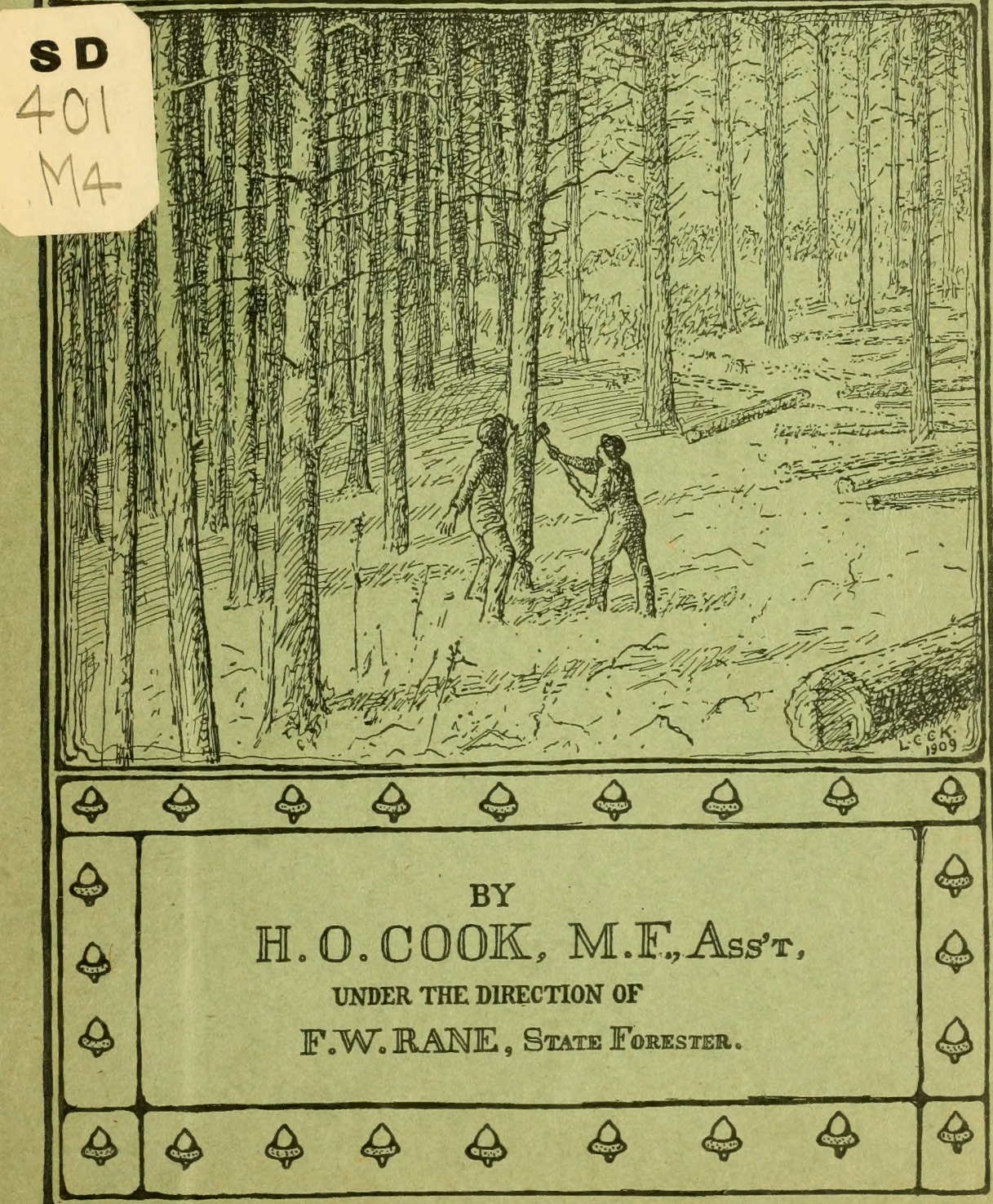




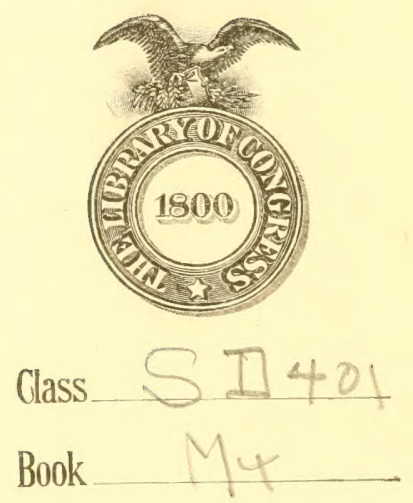








\section{HOW TO MAKE}

\section{IMPROVEMENT THINNINGS}

IN

MASSACHUSETTS WOODLANDS

BY

H. O. COOK, M.F., Assistant

UNDER THE DIRECTION OF

F. W. RANE, STATE FOREster

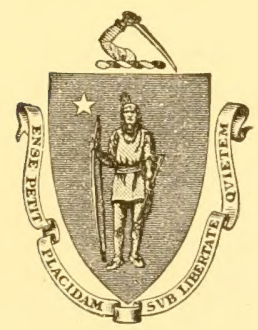

BOSTON

WRIGHT \& POTTER PRINTING CO., STATE PRINTERS

18 POST OFFICE SQUARE 


$$
\frac{s^{2}}{m+1}
$$

APPROVED BY

The State Board of Publication.

D. OF D.

IAN 281910 


\section{INTRODUCTION.}

This bulletin is published by the State Forester that our people may have at their disposal the information so often desired on the thinning of woodlands.

In 1905 the Massachusetts State Forester published a small pamphlet on "Improvement Thinnings." The edition of this pamphlet has long since been exhausted.

The present treatise enlarges on the subject, and has much additional value in that it contains data and illustrations taken from actual experiments.

While it is believed that after studying this pamphlet carefully a man of good judgment should be able to go into his woodlot and select approximately at least the right trees to be thinned out, yet it must be said that the problems of thinning are many and diverse, and it is impossible to give more than the general theory in a publication like this.

Your attention is called to the policy of this office in sending out trained foresters at the request of any owners of woodland in the State. The forester will go over the land with the owner or his agent, and will explain to him his ideas on its treatment. The expense to the applicant for this advice is merely the travelling expenses of the visiting forester. Application blanks for such work can be had through your local forest warden, or by sending directly to the State Forester's Office.

\section{ACKNOWLEDGMENTS.}

The work of writing and compiling the data in this bulletin was done by my assistant, Mr. H. O. Cook, M.F., who was assisted by Mr. H. F. Gould, M.F., in the field work.

Particular attention is also called to the "Report on the Practical Thinning of a White Pine Woodlot," at the end of the bulletin. This work was accomplished under the direction of a former assistant, Mr. J. J. Dearborn, who did the work so well that the Diamond Match Company sought his services.

F. W. RANE, State Forester.

6 Beacon Street, Boston, Mass., Dec. 24, 1909. 



\section{HOW TO MAKE IMPROVEMENT THINNINGS IN MASSACHUSETTS WOODLANDS.}

\section{IMPORTANCE OF THINNING.}

By improvement thimnings and cuttings we mean the systematic removal of a portion of the trees in a growing forest, in order to benefit the portion that remains. It is the forester's method of cultivation, and it is the only practical way he has of increasing the yield and improving the quality of his crop. The methods of the arboriculturist are, except in limited cases, ton costly to have a place in practical forestry.

Those people who doubt the value of forestry practices often argue against thinnings, on the ground that nature"s methods must be the best. It is no more true that nature's methods are best in the forest than in the orchard or garden. The practice of thimning in European forests for nearly one hundred years has established leyond a doult that this work increases the amount and quality of the lumber. In 1830 the average annual growth in German forests was 20 cubic feet per acre, while in 1904 it was 65 cubic feet, - an increase of 300 per cent., which can be attributed almost entirely to the methodical thinning of their forests.

Nearly 45 per cent. of the land area of Massachusetts is covered with some form of woodland growth, which can be apportioned romghly among three main types: the pine forest, which has come up on alandoned fields and pastures: the inived growth, composert of hard woods, usually of seedling origin; together with pine and hemlock and sprout forest. Dbove an altitude of $1: 200$ feet spruce replaces pine. A seedling tree is one which has come from a seed or nut; and by a sprout we mean one which had its origin in a sucker sent out by a stump from which a tree has been cut.

The principles of thinning apply to all kinds of forest, but it is perhaps the sprout land which chiefly needs improvement. It is the largest single type, and yet, with the exception of sprout chestnut, which is used for ties and poles, this sprout land is at present producing nothing but cord wood. Proper care might bring these cord wood stands to producing saw timber. 


\section{THEORY OF THINNING.}

In order that one may understand the principles which underlie the process of thinning, he must know something of the physiological growth of single trees, and of that collection of trees known as a forest.

Plants are marle 1 p of tissues composed of mumlerless small cells. 'These cells are largely composed of carbon derived from the carbon dioxide of the air and water. The carbon dioxide enters into the leaves through minute pores (stomata), and by the action of the sunlight on the green chlorophyll grains, the process of assimilation, which in plants answers to digestion in animals, takes place. 'The carbon is combined with the water and a small amount of mineral matter taken from the soil by the roots to form the growing material of the plant, while the oxygen is returned to the air. 'Therefore any crowding or shading which deprives the tree of these necessary agents, foliage and sumlight, checks its rolume growth in proportion.

To take a simple example, let us suppose a plantation set out with seedlings 6 by 6 feet apart; then there will be 1,210 trees on an acre, and each tree will have 36 square feet in which to spread its branches. When the side branches meet we have what is called a closed stand, and a struggle commences. It is characteristic of trees to take all the room they can get; and not having any more at the sides, they seek the sunlight by growing upwards at a rapid rate. 'Trees even of the same species differ in their rate of growth, so that some get ahead of the others; and when they do, they spread out their side branches and so overtop their weaker neighhors. Unless these overtopper trees happen to be in the class called by foresters tolerant, i.e., shade-bearing, they will soon sicken and die. By the time our plantation is fifty years old, only 300 trees will remain of the original 1,210 .

In the early life of the forest, say the first fifteen to twenty years, a sharp conflict of this kind is very useful, for it produces all tall, straight tress: in the second place, on account of the dense crowding the side branches are killed off when young, and the tree is free from knots; and in the third place, the ground is kept shaded and the moisture retained in the soil. After twenty years growth, however, these objects have been accomplished, and then the forester steps in and opens up the stand so as to allow the crowns to spread. Larger crowns mean, of course, a more rapid incrase in volume growth. Furthermore, the slower-growing trees 
are removed while they are still alive and fit for use, and are not allowed to gradually sicken and die, an invitation to insects and diseases of the forest.

In the case of sprout land the crowding is generally more severe and the neet of thimning more urent than the plantation supposed above, for from every stump 10 to 50 suckers may spring, so that several thousands of young trees may start up on an acre.

\section{PRACTICE OF THINNING.}

WHEN TO THIN.

The conditions which exist in most parts of this country do not permit us to thin as early or as often as is desirable. The market for small-sized wood is uncertain, and we must be satisfied with a less intensive cultivation of our forests than our European friends enjoy.

A safe rule to follow is to thin a stand as soon as the material to be removed has reached such a size that its sale will pay the cost of the removal, and as soon again as the material to be removed has accumulater in sufficient quantities to pay the expense involved. The profit is to be found in the improved growth of the stand. When the woodlot owner is a farmer, or has farm help during the winter months, when they might be idle much of the time, the net cost of the work may be held quite low.

A less commercial and a more scientific rule would state that a thimning should be made as soon as the trees have attained their maximum rate of height growth, and the lower limbs are well pruned off. In practice this would mean a moderate thinning when the stand is from twenty to thirty years old, and a heavier one ten to fifteen years later. If the rate of growth of our native trees and their response to treatment were better known, we could afford to thin at some net expense, being able to calculate what the profit would be; but unfortunately American foresters have not had time to gather the necessary data on this subject, and until we do, the rule of letting the material pay the expense is the best to follow.

\section{What to Thin.}

The extent to which a closed stand may be opened up depends on several circumstances. Species which are called "tolerant," because they stand the shade well, should be kept quite thick, for they cling tenaciously to their side limbs. Hemlock and beech are extreme examples of "tolerant" trees. A forest on a dry, 
sandy soil or on a hill top should not be thinned as hearily as one on low, moist ground; because under such circumstances the soil must be kept shaded to retain the scanty supply of moisture. The age of the trees and the kind of timber desired have an influence on the decision of what to take. For instance, if the owner of a chestnut sprout stand wishes it to rield poles rather than ties or lumber, he should thin it lightly.

The simplest problem of thinning is in a woodlot consisting of but one species. We first divide the trees into four classes: dominant. intermediate, suppressed, and dead. Dominant trees have large, full crowns, well up in the light. Intermediate trees receive light from above, but are somewhat crowded at the sides, some more than others. Suppressed trees are those which have been wholly overtopped by their more vigorous neighbors, and are slowly dying. A moderate thinning would consist in the removal of the intermediate trees which are closely pressed by their neighbors, ant all the suppressed trees if they will make a marketable product. Dead trees do no injury to the growing crop, and are nnly removed to improve the appearance of the woods, or as a precaution against fires.

When the woollot contains a number of species the problem becomes more complicated, for we have the relative value of species as another factor which we must consider. The relative worth of different species depends in part on their value in the market; in part on the owner's plans as to the final disposition of the woodlot; and in part on their adaptability to the soil in which they are growing.

The hard woods of the eastern part of the United States are divided into two types: the northern and the southern. Generally spealing, the orter of preference in the northern hard woods would be rock maple, paper birch, yellow birch and beech. Among the southern hard woods the names might be arranged as follows: chestnut, white ash, red oak, hickory, white oak and soft maple. Gray birch, poplar and wild cherry are usually classed as forest weeds, and are taken out. Where these latter three species are growing by themselves, and are not interfering with other and better trees, they can of course be left; but they are not worth any improvement work.

Where white pine is mixed with deciduous trees, it is usually farored at their expense; and spruce in the higher altitudes should be similarly benefited. Pitch pine, however, is in a class below 



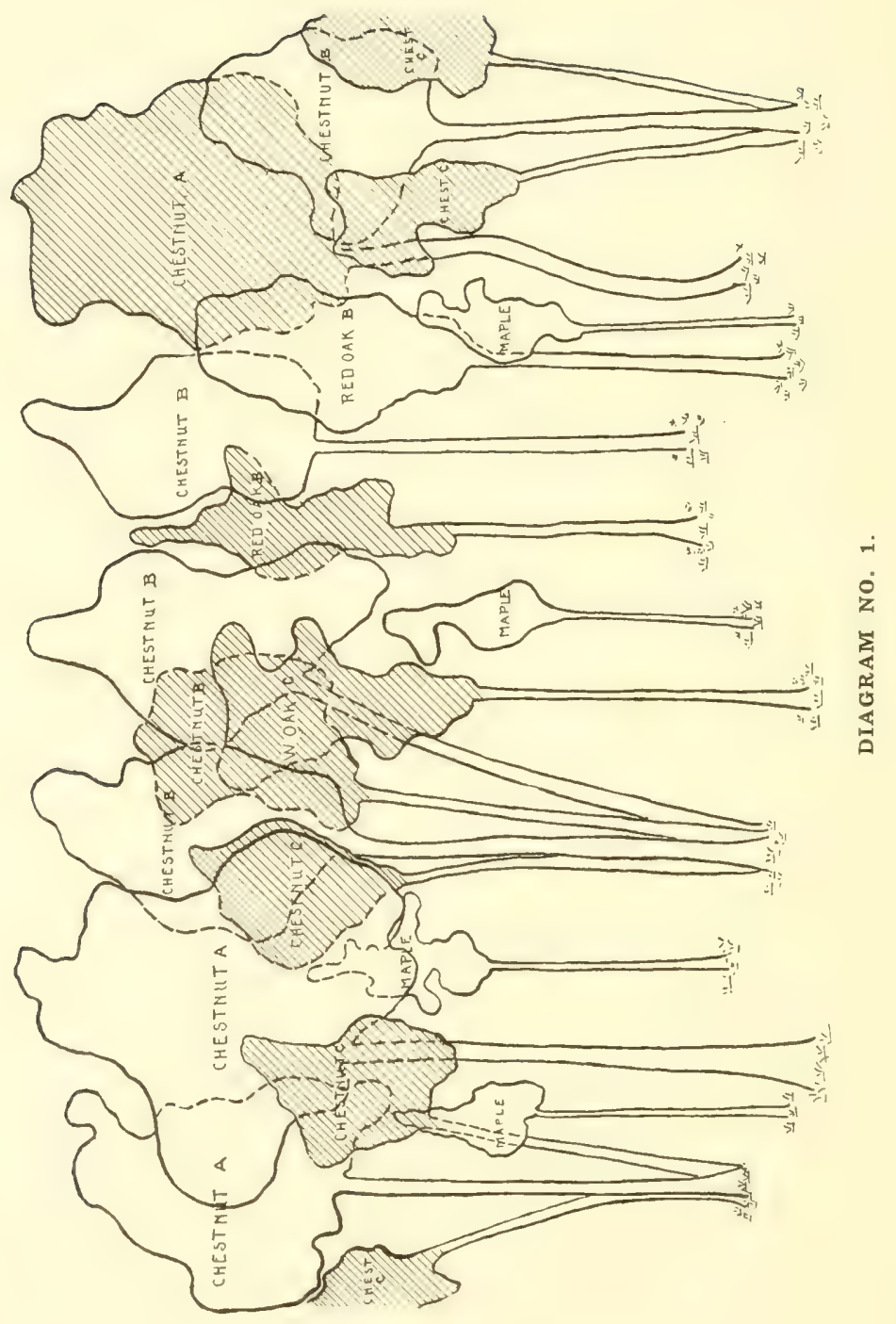


the better hard woods; and there is no call to favor hemlock, because it is very "tolerant."

After the trees have been classified and the order of preference by species determined upon, a third cousideration must enter into our calculations. Defects, such as decayed trunks, fire scars or extreme crooks, are a sufficient reason for the removal of a tree; so that it is not impossible to lhave a woodlot in which the dominant trees, being in poor condition or of a ralueless species, would be removed. Such a cutting could, however, scarcely be called a thinning, but would rather partake of the nature of an improvement cutting.

One can readily understand that the man who is put in charge of a thinning operation must have sound judgment, and be well instructed in the principles of the work. Where possible, it is well to have a trained forester mark the trees to be cut. It is better to be conservative rather than radical in the selecting of the trees to be removed, as a thinning which is too light can be easily remedied, but one which is too heary will take years to mend. A mere cleaning up of the underbrush and a few suppressed trees is not a thinning, however.

In practice it is customary to blaze the trees to be cut, and often they are blazed twice, once about $t$ feet from the ground, and once low down on the stump. Unless one has great confidence in his man, it is not wise to let the chopping out at so much a cord, because as a rule in a thinning operation we take only the smaller and poorer trees, so that the chopper is under a great temptation to increase his pile by taking some of those intended to be left, and it is difficult to detect the fraud.

\section{Explanation of Diagrams.}

We have encleavored to represent in Diagram No. 1 a section of a typical sprout chestnut stand, 50 feet in length and 20 feet in width. The trees of the dominant class are marked $\mathrm{A}$; the intermediate class, B; and the suppressed trees, D. The small maples, although apparently suppressed, are not so; but, being very tolerant of shade, they have come up under the shadow of the chestnuts, and form a sort of second cover. The trees removed in thinning include five suppressed, two intermediate and one dominant. The dominant chestnut was removed primarily because of its poor, crooked bole, and secondarily because there was a good red oak and a chestnut rearly to grow into the vacated space. The maples 
were not cut, because they were so small that they could not interfere with the larger trees, and they help to keep the ground shaded until the broken cover is re-established. Diagram No. 2 represents the stand as it appeared after the thinning.

Diagram No. 3 represents a group of six sprouts, originating from a single stump. They range from 4 to 8 inches in diameter, and from 45 to 55 feet in height. It is difficult to show on a flat piece of paper and hy a diagrammatic drawing the sprouts as they were actually placed around the central stump; but in the space allotted by nature to the group they were overcrowded. 'The problem was then to reduce their number in such a way that the crowns of those that remain will utilize the limited space to the best advantage. The drawing marked "After" shows how this was done. The diagram does not inclicate very well why the left-hand sprout should have been taken away, but its removal was determined by its relation to neighboring trees not shown in the picture.

\section{RESULTS OF THINNING.}

We said in the section on the "Theory of Thinning" that the more light and air a tree receives, the more rapidly it grows in diameter: so that a thinning, by opening up the stand and allowing the crowns of the remaining trees to enlarge, stimulates the rolume growth of the stand. There are fewer trees in the stand. hut larger and better ones. This may not be considered important until we realize how much more valuable a tree of large liameter is than a small one. For example, the average white pine, 10 inches in diameter breast high, and 60 feet in height, contains 9.) feet of round-edge lumber; whereas a pine of the same height, 15 inches in diameter, contains 195 board feet of lumber. That is, with a 50 per cent. gain in cliameter there is an increase of 100 per cent. in the product. This is not the whole story, because with the increase in the size of the tree the boards are wider and have less knots, viclling a higher price; so that the gain in money value is even greater than the increase in volume. An average chestnut tree 10 inches in diameter will produce 2 ties and .03 cords of fire wood. Supposing a railroad tie to be worth 50 cents, the tree may be said to he worth ahout $\$ 1$. A 15 -inch chestnut will yield 5 ties and .06 cords of wood, worth about $\$ 2.50$, or an increase in money value of 150 per cent. In the case of sprout oaks and other sprout hard woods, thinnings marle at the right time may result in conrerting what would otherwise be nothing but a cord-wood lot into one of saw-timber size. 


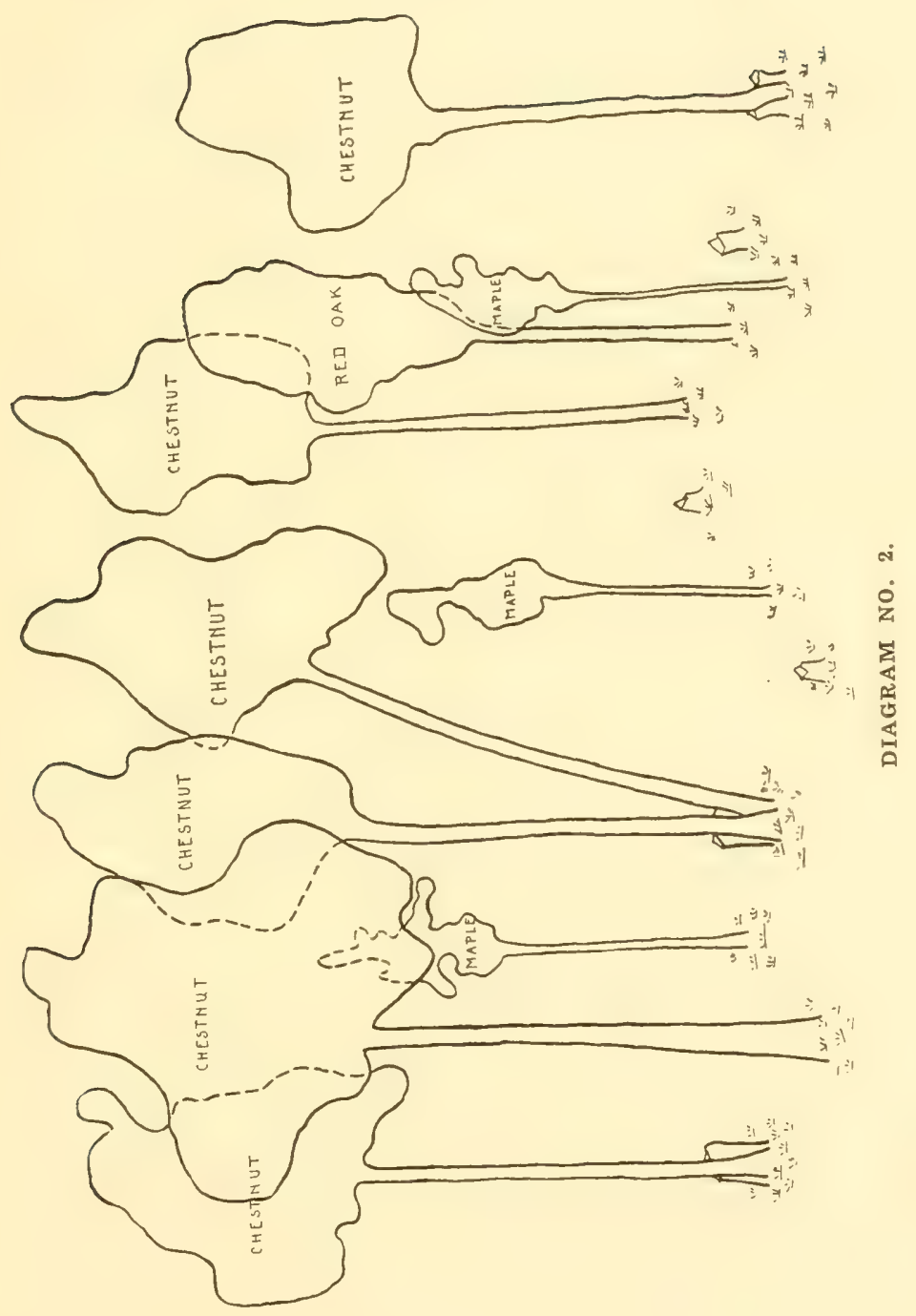





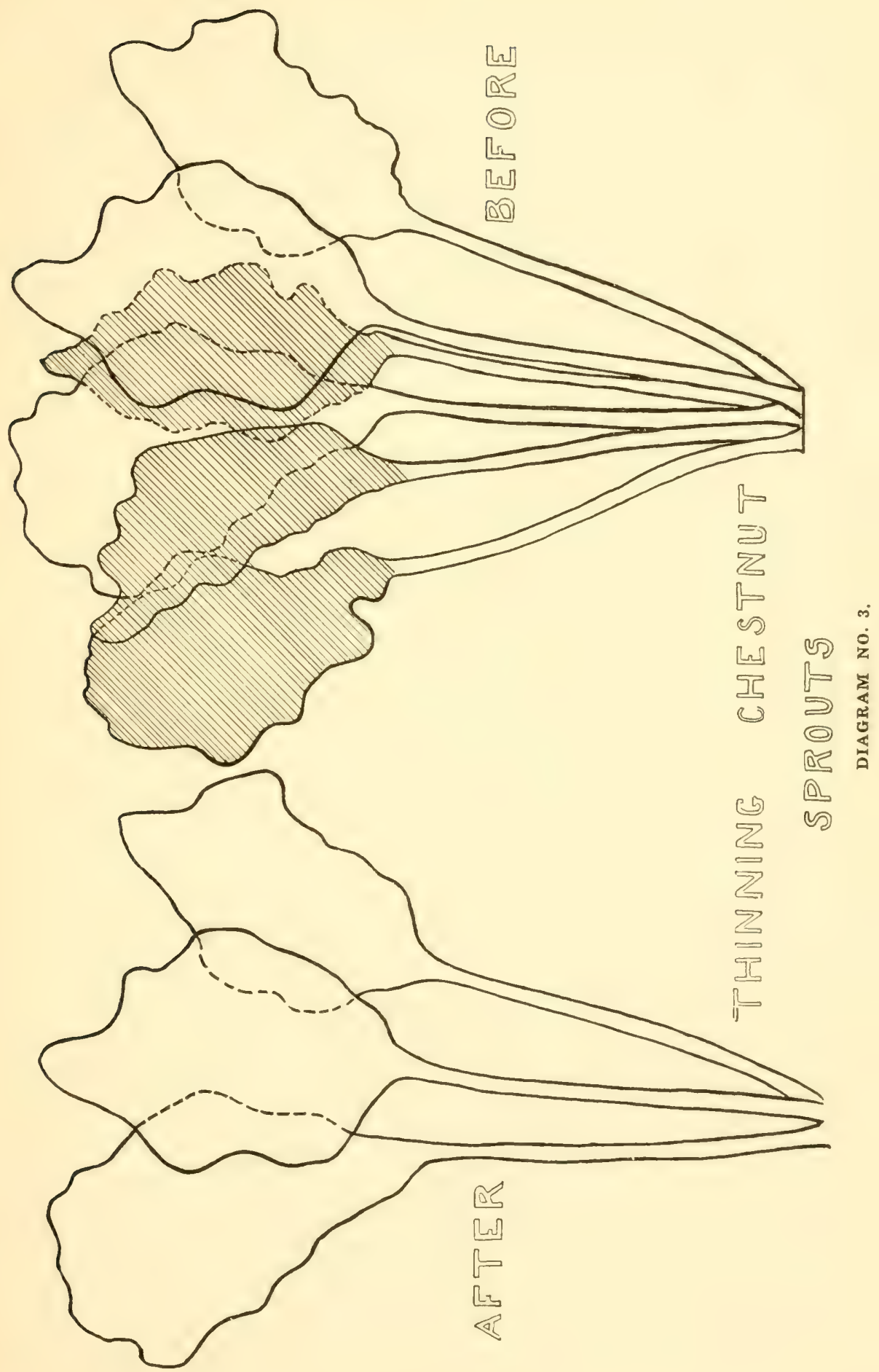



If as a result of thinning the trees become larger in a given space of time, conversely they will attain any suitable size in a shorter space of time than without a thinning. The experiments of European foresters have shown that the rotation of the timber crop can be shortened by judicious thinnings from 10 to 20 per cent.

In the course of this work many unsightly and diseased trees are removed, and this fact tends to make the woodland more attractive to the eye. Where forest land is used for park purposes as well as for timber production, a moderate thinning is highly recommended. It should, however, be conducted under careful supervision, as the tendency is often towards a "sand-papering" treatment of the woorls, to which many people who love primitiveness in nature object; and they wrongfully believe this effect to be a necessary result of forestry work.

\section{IS THINNING PRACTICABLE?}

There are many owners of forest property who, although they do not doubt that a thinning will benefit their woods, say that the cost of the work is prohibitive. Of course there are many places in this State so remote from a market that the product will not even pay the charge for labor; but the trouble with most of these people is, that they want to get back their wages, a fair stumpage, and often an additional profit, from work meant for improvement only. It is an especially valuable line of work for the landowner who is obliged to keep men and horses through the winter months, with little for them to do. Such a man makes something out of the thinning work, no matter if the actual returns are small.

In the sprout hard-wood stands, from 3 to 8 cords will be found to be the usual product of thimnings, depending on the age and density of the stand. In the seedling hard woods am mixed stands the density is so variable as to make any definite statement in regard to the probable product of thinnings impossible. As a rule. ahout one-third of the trees and from one-fifth to one-quarter of the total volume in the woodlot are taken out in this work.

Two years ago this office published a small pampllet containing data on the white pine. Part of this booklet was given over to yield tables. A pine yield table is one which shows the volume of well-stocked pine stands at different ages, which in this case ranged from twenty-five to fifty-five years. These tables were made by measuring the trees on many sample plots of all ages, and averaging the results. When these sample plots were calipered, those trees 
which would be removed if the stand was thinned were noted separately. From this data a table of the yield from pine thinnings was made and published at that time. We print it again in this pamphlet, on account of its connection with the subject.

YIELD FROM THINNINGS.

Trees under 5 inches, from report of the New IIampshire Forestry Commission, 1906.

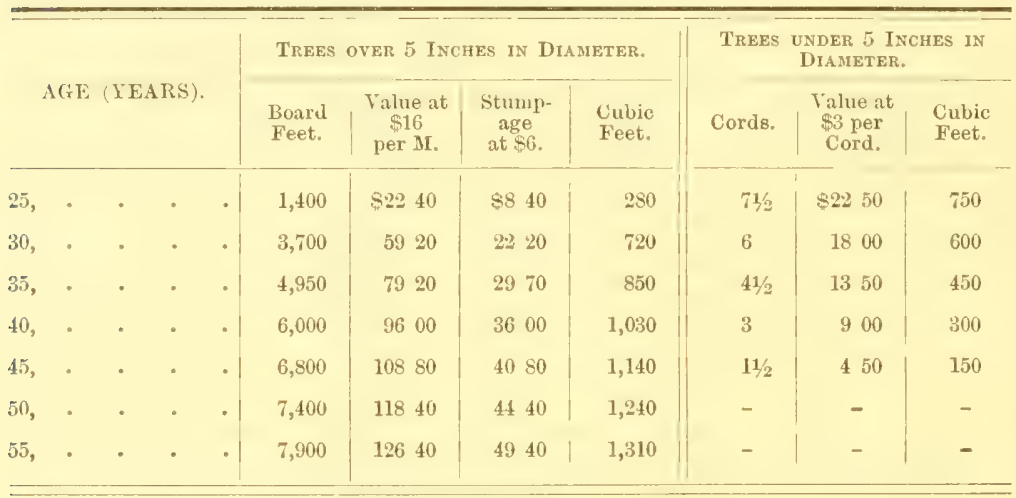

\section{MISCELLANEOUS CUTTINGS.}

There are many kinds of cuttings which one can make to improve woodland, which cannot strictly be called thinnings, because their primary object is not to open up the crown cover, in order to stimulate the growth of the trees. It is not always possible to draw a hard-and-fast line between such improvement cuttings and thinnings, because one may partake of the nature of the other, and the two may be carried out at the same time. Such cuttings can best be suggested by a few examples.

We will suppose that an insect pest which attacks some particular species of tree, for instance, maples, is more or less prevalent in a region. As a matter of protection, the owner of mixed woodland might go through it and take out all the maples, so as not to attract the insects to his land. The removal of hard woods from a pine stand as a precaution in fighting gypsy moths is another protection cutting. which we have described elsewhere in this bulletin.

One often finds among the woods large, spreading old trees, more or less decaved and of little value for timber. It is good forest policy to cut such trees down, and to allow the large amount of ground space which they occupy to come up to a new growth of more value. 
In old, abandoned pastures we often see young pines coming up underneath a stand of gray birches. While the pine seedlings are very young, let us say not more than four or five years old, the birches protect them from the hot sun and wind, and act in the rôle of nurse trees. But as the pines increase in size, they need the sunlight; and, further, the branches of the birches, as they sway in the wind, cut the tender leading shoot of the pine, killing it and causing the tree to be stunted and crooked. In such cases the birches should be removed; but if they are too small to make cord wood, or if the young pines are scattered, it is only necessary to remove the trees immediately surrounding the pines. If done in this manner, one man can easily cover an acre or two a day.

If diseased or decaying trees are removed from a stand with no special reference to the principles of thinning, the operation is an improvement cutting, and not a thinning.

\section{THINNINGS IN GYPSY MOTH WORK.}

Nowhere are thinnings more useful than in woodland infested with the gypsy moth. The cost of the work against this pest, may it be spraying, burlapping, or creosoting egg clusters, is in a large measure proportional with the number of trees to be treated. One of the first methods used in the work against the gypsy moth in woodlands is to remove the underbrush, and in that way reduce the material to be worked on as much as possible; and it is extremely beneficial, as well as advisable, at the same time to carry on a scientific thinning, and remove from the woods all the trees which will not compose the final stand.

A thinning made in preparation for the work against the gypsy moth should be of the heariest nature possible, consistent with a fair protection to the soil.

A change is also necessary in the preference of species, the gypsy moth being especially fond of oaks; and it is also hard to detect the egg clusters on white oaks, so that as far as possible they should be removed from the final stand. The gypsy moth caterpillars do not seem to be as fond of hickory, walnut, ash, chestnut or swamp maple as they are of most of the other species of deciduous growths. From experiments whicl? haw heen carried on in a very thorough manner, it has ben proven that the small gypsy moth caterpillar cannot feed $u_{1}$ s? the conifers; and where thinning operations are being carried on, and a mixed growth must be taken into consideration, it is advisable to separate the conifers from the deciduous growth, thus giving an opportunity to use tanglefoot and protect 
the conifers, as they do not hold as much poison as the broadleaved trees. Also, where pine stands have a small scattering of decirtuous growth mixed with them, they may be spared from the rarages of the gypsy moth by remoring all deciduous trees, and in that way insure the owner permanent protection, proriding he protects the border of the coniferous growth.

It might be well to mention that the brown-tail caterpillars will not feed upon the coniferous growth.

Within any part of the State where there is danger of a moth infestation, the woodland owner will not only improve the condition and growth of his forests hy thinning, but will be in a position to combat these pests in a more effective and economical measure than otherwise.

\section{EXPERIMENTAL WORK.}

The office commenced this fall to make some permanent sample plots, with the purpose of obtaining lata on the growth of thinned stands.

The first of these plots was in a sprout chestunt stand of thirty years' growth, situated near the bottom slopes of the northeast face of a rocky hill. The soil is thin, but fertile and moist. The sample plot covered 1/2 acre, and within this area the trees to be removed in the thinning were blazed. All the trees were then calipered, the blazed trees being noted separately from the others, with the result that the total stand on the $1 / 2$ acre amounted to 15 cords of chestnut and 2 cords of miscellanenus wood. The following table represents the tally sheet. and shows the different species and their proportion in the mixed growth. The trees in Class II. are those that were marked for thinning. 
SAMPle Plot for Chestnut THINNing ( $1 / 2$ ACRE).

\begin{tabular}{|c|c|c|c|c|c|c|c|c|c|c|c|c|c|c|c|}
\hline \multirow{2}{*}{\multicolumn{4}{|c|}{$\begin{array}{l}\text { DIAMETER } \\
\text { BREAST HIGH } \\
\text { (INCHES). }\end{array}$}} & & \multicolumn{5}{|c|}{ Class I. } & \multicolumn{6}{|c|}{ Cluass II. } \\
\hline & & & & & 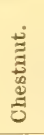 & 离 & 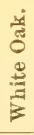 & 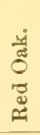 & 竎 & 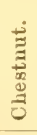 & \& & 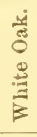 & $\begin{array}{l}\frac{\text { है }}{5} \\
\text { एँ }\end{array}$ & 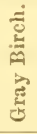 & ֻัّ \\
\hline 2 & . & - & . & & - & 5 & - & 2 & - & - & 20 & 5 & 3 & 9 & 3 \\
\hline 3 & . & . & . & • & - & 3 & 2 & 1 & - & - & 15 & 17 & 7 & 18 & 16 \\
\hline 4, & - & . & . & - & - & - & 2 & 2 & - & 4 & 3 & 5 & 2 & 1 & $2: 2$ \\
\hline 5, & . & . & - & - & 1 & 2 & 2 & 2 & - & 15 & - & - & 2 & - & 5 \\
\hline 6, & . & . & . & . & 11 & - & - & 1 & - & 24 & - & - & - & - & 2 \\
\hline 7, & - & - & . & - & 22 & - & - & - & - & 16 & - & - & - & - & - \\
\hline 8 , & - & - & - & - & 20 & - & - & - & - & 4 & - & - & - & - & - \\
\hline 9 & . & - & . & - & 25 & - & - & - & - & 3 & - & - & - & - & - \\
\hline 10 , & . & . & . & - & 13 & - & - & - & - & 3 & - & - & - & - & - \\
\hline 11, & - & - & . & - & 3 & - & - & - & - & - & - & - & - & - & - \\
\hline 12, & . & - & - & - & 2 & - & - & - & - & - & - & - & - & - & - \\
\hline 13, & $\cdot$ & - & . & - & 1 & - & - & - & - & - & - & - & - & - & - \\
\hline & Totals, & & . & - & 38 & 10 & 6 & 8 & 0 & 69 & 38 & 27 & 14 & 28 & 48 \\
\hline
\end{tabular}

\section{Average Heights.}

Chestnut, Class I.,

Feet.

Feet.

Chestnut, Class II.,

Red oak, Class II., . . . . . . 35

Red oak, Class I.,

White oak, Class II., . . . . 37

Red maple, Class II., . . . . . 24

The marked trees were then cut down, chopped into 4-foot bolts, and piled as follows (only the larger, sound dead wood was cut into cordwood) :- -

Trees (not bolts) 5 to 7 inches breast high diameter,

Cords.

Trees (not bolts) 7 to 9 inches breast high diameter,

1.3

Trees (not bolts) 3 to 5 inches breast high diameter,

Trees (not bolts) 1 to 3 inches breast high diameter,

Dead wood,

To summarize, if this entire chestnut lot, running 30 cords to the acre, were thinned, we would take out more than one-half the total number of trees yielding about 6 cords of wood per acre, or one-fifth of the total volume.

Unfortunately, a fire ran through the woodlot soon after the work was completed, and, although it was not hot enough to injure 
the trees severely, their growth will be impaired in some degree, and the value of the lot for future measurements is destroyed.

In the town of Petersham we found an old pasture, containing a thick growth of gray birch, among which a lot of young pines now about twelve years old showed in an ideal way their struggles to get above their grasping neighbors. A half-acre sample plot was measured off, and all the birches cut on one-half of this plot. The other quarter-acre was not touched, so that there could be a comparison made of the difference in the growth of the pine on the inproved and unimproved sections. If our theory proves correct, a very few years will suffice to show the difference.

Two men spent two and one-half days in getting out the birch and piling the brush, and the usable product was 4 cords of fire wood.

In the fall of $190 \% \mathrm{Mr}$. J. J. Dearborn, then assistant in this office, markerl for a thinning a pine lot of 12 acres, belonging to Dr. P. W. Goldsbury, in Warwick, Mass. When the time came to let out the contract for chopping the trees, no lumberman would take it, saying that such work was impracticable, as it would be impossible to fell the trees without lodging them. Mr. Dearborn then gathered together a crew of his own, employing them as day laborers. After spending a couple of weelis with them at the start of the work, he allowed the crew under the direction of a practical woolsman to complete it, and the result was satisfactory in every way. No insurmountable difficulties appeared in either the chopping or the logging.

Ir. Dearborn's report, describing the conditions, explaining the methods of work, and showing the financial results, forms a valuable document, and we herewith reproduce it.

\section{REPORT ON THE PRACTICAL THINNING OF A WHITE PINE WOODLOT.}

INTRODUCTION.

The following report is a record of the conditions and facts connected with the experimental thinning of a white pine woodlot in Warwick, Mass., belonging to Dr. P. W. Goldsbury.

\section{The Tract.}

The tract extends over an area of 12 acres of gradual swales and ridges at the bottom of a valley. Excepting for a small area where a ledge outcrops or lies very near the surface, the soil is a deep, sandy loam of good moisture, and everywhere well drained. 


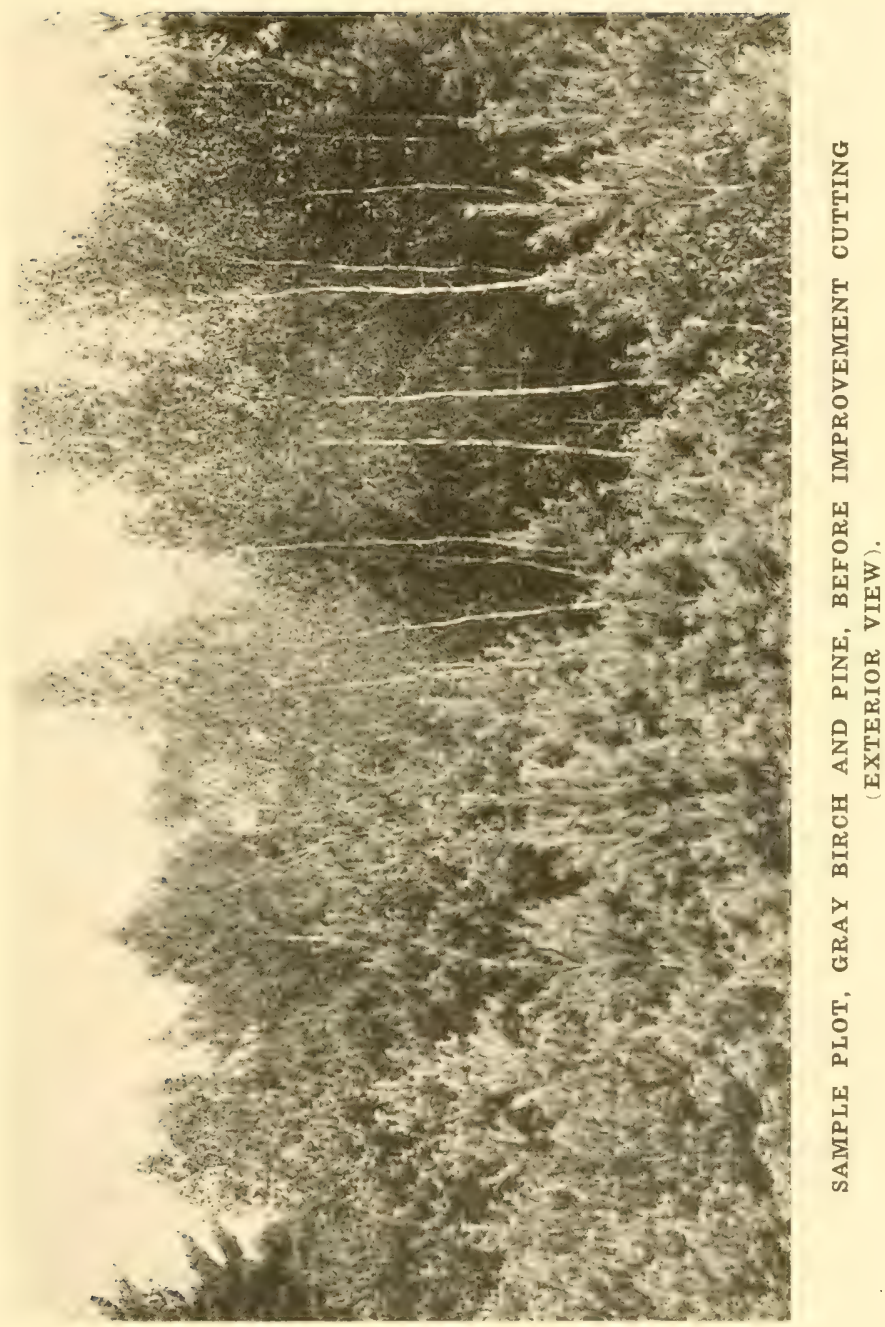





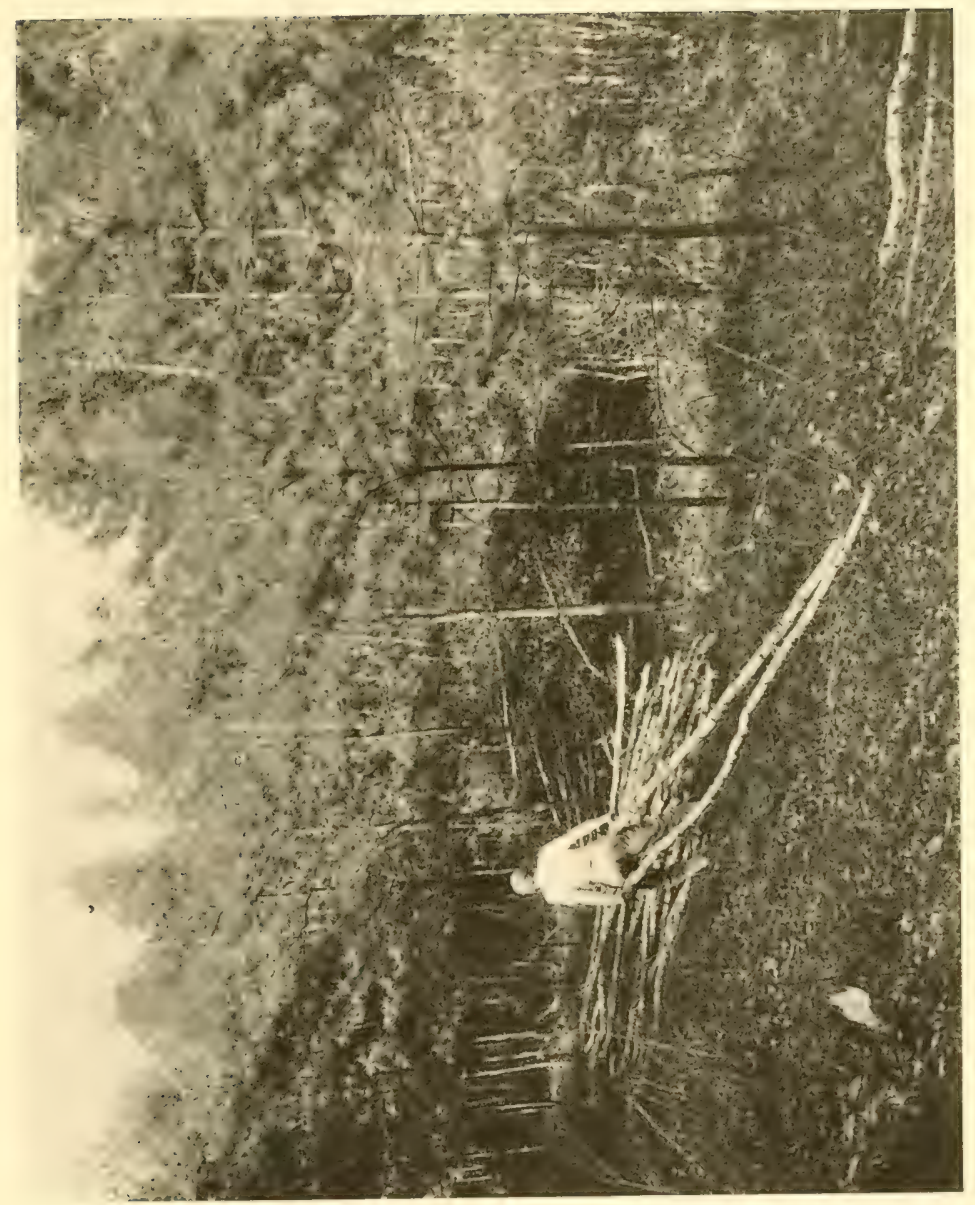



The stand, which averages fifty years of age, is interrupted by two small ponds from being a block of solid growth. This growth is a result of a natural seeding of an old pasture. As a result of this natural seeding, there are represented two conditions which governed the policy of the thinnings, - the first that of a dense condition where the trees had practically started at the same time and grown up to form an even-aged stand, tall and comparatively clean of their side limbs. A sample plot taken in this condition will better illustrate it:-

Plot $1 / 4$ ACre, Souti of BaptisM POND, in Direction of tile House.

\begin{tabular}{|c|c|c|c|c|c|c|c|c|c|c|c|c|c|c|c|}
\hline & & \multicolumn{14}{|c|}{ Diameter Breast Hrah (Inches). } \\
\hline & & 6 & 7 & 8 & 9 & 10 & 11 & 12 & 13 & 14 & 15 & 16 & 17 & 18 & 22 \\
\hline No. of trees, & . & 3 & 5 & 3 & 9 & 8 & 4 & 7 & 7 & 7 & 3 & 4 & 2 & 2 & 2 \\
\hline
\end{tabular}

A total of 66 trees, or 264 to the acre, with a height of 65 to 70 feet.

PLOT $1 / 4$ ACRE, ON THE FLAT IBETEEN THE TWO P'ONDS.

\begin{tabular}{|c|c|c|c|c|c|c|c|c|c|c|c|c|c|}
\hline & & \multicolumn{12}{|c|}{ Diameter Breast High (Inches). } \\
\hline & & 5 & 6 & 7 & 8 & 9 & 10 & 11 & 12 & 13 & 14 & 15 & 16 \\
\hline No. of trees, & . & 2 & 3 & 12 & 12 & 13 & 14 & 12 & 6 & 9 & 4 & 3 & 1 \\
\hline
\end{tabular}

A total of 91 trees, or 364 to the acre, with a height of 60 to 70 feet.

A better idea of the density of these trees can be realized if it is known that 302 trees spaced regilarly over an area would he 12 by 12 feet apart.

The other condition was that where a few trees had started and developed very wide spreading, and with large side limbs near to the ground. The density varied from a condition where the side limbs of the trees came together and completely shaded the ground, to where the trees stood with open spots and areas about them. In these open areas there was almost always a good reproduction of white pine coming in among the blueberry, huckleberry and kalmia bushes. The following sample area was taken where the pines had a great deal of room about them, with a good reproduction of pine coming in:-

Plot $1 / 4$ ACRE, Northeast of large POND, in Direction of A Field.

\begin{tabular}{|c|c|c|c|c|c|c|c|c|c|c|}
\hline & & & & & & \multicolumn{5}{|c|}{ Diameter Breast High (Inches). } \\
\hline & & & & & & 9 & 16 & 18 & 22 & 24 \\
\hline No. of trees, & - & - & - & . & - & 1 & 1 & 1 & 1 & 1 \\
\hline
\end{tabular}

A total of 5 trees, or 20 to the acre, with a height of 55 to 60 feet. 


\section{OWNER'S DESIRE.}

It was Dr. Goldsbury's first desire not to mar the beauty of his farm, or to make his woodlot an eyesore to the village of his town by cutting and stripping the land of its fine growth. Furthermore, he desired to take such steps as would improve his lot and place it in a more flourishing condition, so that it would come down to the younger generation unimpaired. Lastly, his diffeulty in getting any one to attempt the thinning of his lot influenced him to sacrifice his woodlot to an experiment which would make a basis of calculations for such work in the future.

\section{General Policy.}

For the first condition above mentioned or the even-aged growth, the plan was to thin out the weak and poorer trees, leaving the good specimens with suffieient room for their tops to spread and develop without retardation for some ten years at least. The ground for this policy was based on the fact that the trees had made their main height growth, and their energies were now towards developing their diameters. The growth in diameter of a tree is in proportion to the size of its top, since the leaves are the laboratories of the food material which goes to make up the growth, - the more laboratories, the faster the growth.

With this theory in mind, actual practice meant leaving the better and more promising individuals with sufficient room about them to allow the tops to grow unchecked for at least ten years. If this is successfully accomplished, the trees will have developed a larger top, more laboratories or a larger feeding area.

The following data shows the proportion of trees in number and volume removed and left on the same area:-

\begin{tabular}{l|r|r|r|r|r|r|r|r|r|r|r|r|r|r|r|r|r|r}
\hline \hline & & $\mathbf{5}$ & $\mathbf{6}$ & $\mathbf{7}$ & $\mathbf{8}$ & $\mathbf{9}$ & $\mathbf{1 0}$ & $\mathbf{1 1}$ & $\mathbf{1 2}$ & $\mathbf{1 3}$ & $\mathbf{1 4}$ & $\mathbf{1 5}$ & $\mathbf{1 6}$ & $\mathbf{1 7}$ & $\mathbf{1 8}$ & $\mathbf{1 9}$ & $\mathbf{2 0}$ & $\mathbf{2 1}$ \\
\hline
\end{tabular}

$\Lambda$ total of 225 removed and 286 now standing; in volume (according to Massachusetts volume tables), 27,050 B. M. feet were remored and 50,140 B. M. feet left; in fact, about two-fifths of the trees in number and one-third the volume were taken out in the thinnings.

For the second condition the policy was that of encouraging a natural regeneration where a good reproduction did not exist, and assisting a good reproduction where it did exist. Wherever the trees were close enough together, so as to form a complete shade, certain 
of the poorer specimens were taken out, allowing light to enter and encouraging the growth of any seedlings.

Wherever a good reproduction had started around or underneath any of these large pines, better known to lumbermen and foresters as the "pasture pines," they were removed, taking eare to destroy as few of the smaller or young trees as possible.

Through the entire work there were not any hard-and-set rules which could be followed entirely, for there was here and there a problem which could be decided only on the spot. Around the edges of the stand, thinning if carried on at all was not very heavy, since it was thought that too much sum and wind would be admitted from the sides. The presence of a ledge outcropping and lying very near the surface in one instance resulted in a very light thinning, since it was thought that the stand on it was liable to windfall. Other local problems were treated in like manner, but as a rule the main ideas were not deviated from.

\section{The Ophrating.}

Every tree to be removed was blazed with a hatchet, in order that the choppers might not make any mistake. In marking, care was necessary in order to mark those with which there would not be any difficulty in felling. Oftentimes it was necessary to remove trees where some difficulty could not be avoided; yet there were also times when a little foresight would olvviate any trouble and still allow good specimens to remain. A little time was sufficient to mark an area which would take some time for the choppers to cover.

The choppers were most efficient in gangs of three. One man, going ahead, would under-cut tree just above the ground and on the side towards which it was to fall. It is remarkable to observe the skill some men have in directing the tree through any small opening by the right position of this under-cut on the tree. The other two men following him would saw just above and on the opposite side of the under-cut until the tree fell. It was the first man's duty now to trim the tree of its side branches and mark the tree into logs with lengths most economical for it to be sawed by the other two men.

This system sounds bunglesome to relate, but, once started, one man should not be interrupted or in the way of the others, and under ordinary conditions the work would be about equally portioned.

Frequently a tree was found so wedged in between its neighbors, their limbs interwoven, or so balaneed in regard to its necessary felling direction, that some means was required to give the tree a start before it would fall. This was overcome in large trees by wedging the stump and bole in the saw-kerf, or in small trees by directing the men to throw their weight against the tree. Other methods were: picking up small trees and carrying them away at the bole in the opposite direction they were to fall; felling other trees against the one which does not start; 
and, finally, the most useful method, - that of turning the tree with a cant-hook, twisting its top in the direction of least support until it gains momentum sufficient to crash to the ground.

The labor of chopping over the 12 acres required 748 hours. Over this area many of the so-called "pasture pines" were removed, which always tended to make the average cost high, since so much time was required to rid them of their side branches. The fact is that the more expensive trees were removed and the least expensive to handle were left.

Good woodsmen are obtained for $\$ 2$ per day, or for 74.8 days an expense of $\$ 149.60$ over the whole work. The logs were sawed "liverun" into 21/8-inch plank with 1 -inch sidings, and according to the mill scale totaled between 125,000 and 130,000 B. MI. feet. Upon the basis of 130,000 feet, the average cost would be $\$ 1.15$ per thousand for the felling and sawing into logs.

The ordinary contracting price when entting clean is around $\$ 1$ per thousand, - sometimes a little more and sometimes a little less; as a rule, however, a little more, getting as high as $\$ 1.30$ per thousand. The chopping of this lot clean would have cost $\$ 1$ to contract.

Since it was foreseen that the removing of the "pasture pines" was sure to add to the average cost of chopping the improvement thinnings, a record was kept of the labor and the material removed from an area where the work was entirely that of thinning. It required 112.5 hours to go over 2.5 acres, where 27,000 feet were removed and 50,000 feet left. At the rate of $\$ 2$ per day, $\$ 22.50$ was the cost of the work of the improvement thinning, or an average of $\$ 0.83$ per thousand by day labor.

The logging of this tract was done upon a low, four-wheeled truek for two horses, since it was found to be more handy in driving about the trees than the ordinary wooden-shod sled or "skid." On snow a traverse sled was used. A few of the trees had to be snaked out with a horse, but ordinarily two men could handle the logs by actually picking them up and carrying them to the sled or truck. The ordinary contracting price for logging this lot would not be over $\$ 1.50$ per thousand, and the additional expense for picking the logs up from among the trees left standing was not over $\$ 0.15$ per thousand.

\section{Conclusion.}

Up to date (December, 1909) there are no bad results in the stand left.

From a practical standpoint there seem to be quite definite conclusions that it is possible to thin out a pine growth fifty years of age with an additional cost of not over $\$ 0.15$ per thousand for chopping and $\$ 0.15$ per thousand for the logging under ordinary conditions.

Joseph J. DearborN. 


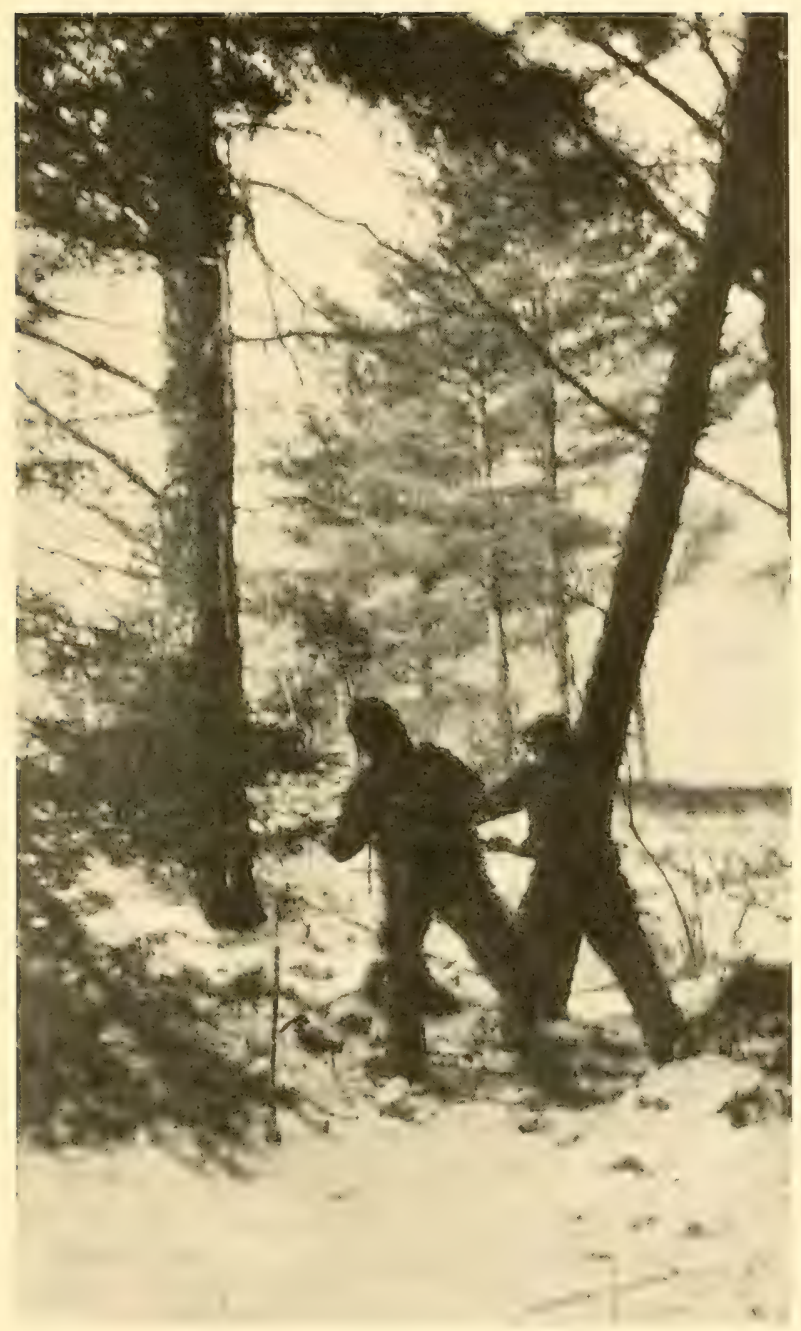

GOLDSBURY LOT, GUIDING THE FALL OF A LODGED TREE RY USE OF THE CANT DOG. 



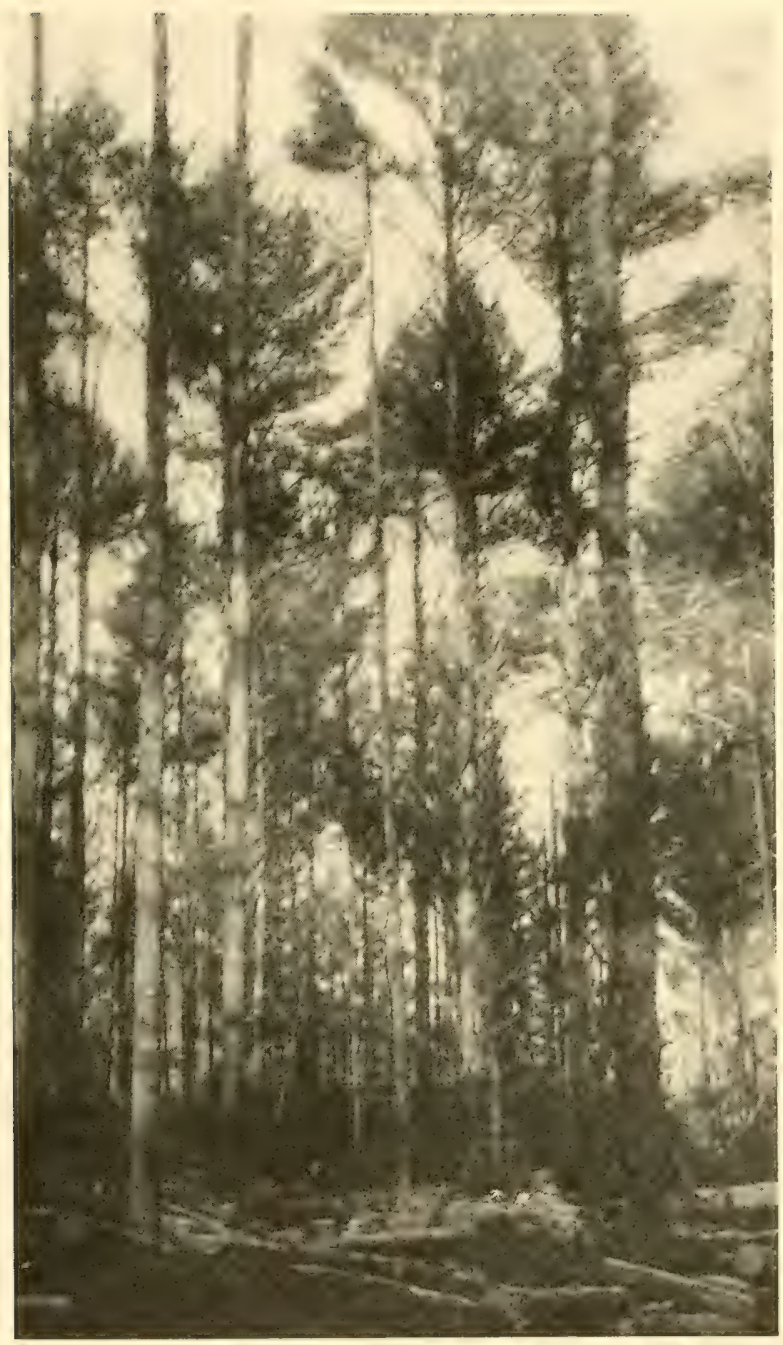

GOLDSBURY LOT, DURING THINNING (INTERIOR VIEW). 



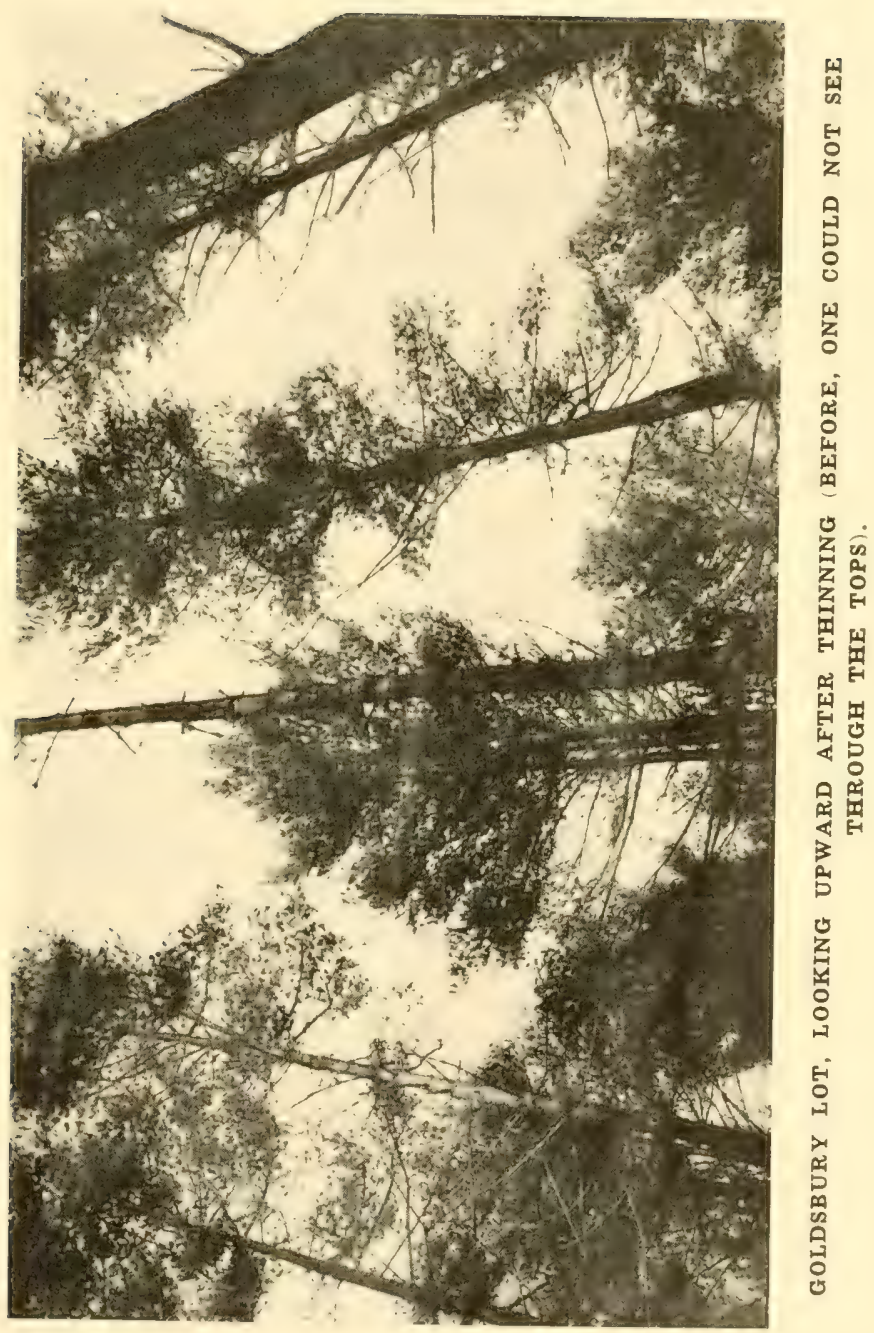





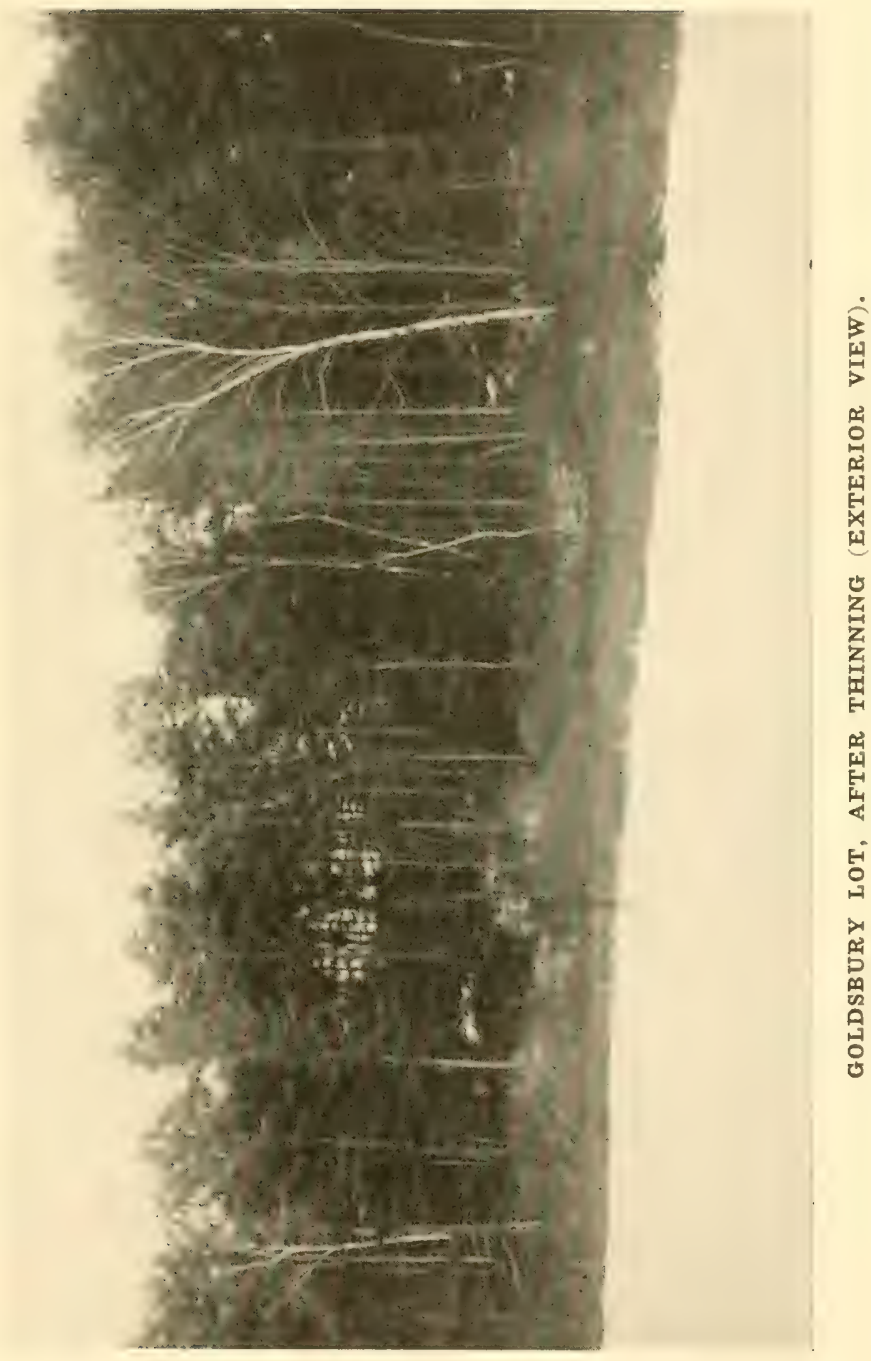





\section{APPLICATION FOR EXAMINATION.}

Should you desire an examination for thinning send to the State Forester for a blank application like the following, fill it out and send it in:-

No.

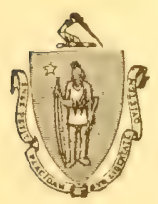

Received

A PPLICATION

FOR AN

\section{EXAMINATION OF FOREST LANDS} TO THE

\section{MASSACHUSETTS STATE FORESTER,}

STATE HOUSE, BOSTON.

The State Forester stands ready at all times to promote the perpetuation, extension and proper management of the forest lands of the Commonwealth, both public and private (190t, chap. 409, sec. 2 ).

If you have such linds and desire an examination of them and advice as to their management, fill out the following blank form and send it to the above address of State F'orester.

Upon receipt, this request will be placed on file, and you will be informed, in orler of application, approximately when the examination can be made, and a mutual date ean then be decided upon.

The only expense the applicant promises to pay is that of travel and subsistence of the State Forester or his assistants. incurred in mating the examination.

It is always more satisfactory to personally meet on the property the owner or party most interested, at least when the preliminary examination is made. In this way a definite understanding can be had as to future undertakings, and whether working plans are necessary. Often a preliminary risit to gin knowledge of the problem and give advice on the grounds are all the services needed.

When sending this application in, a brief description of the land will assist us.

Tith the above understanding, I desire to have an examination made

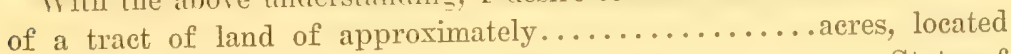

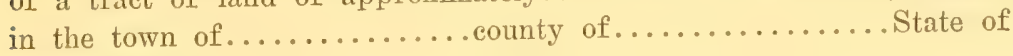
Massachusetts.

\section{Signed}

Address

Date................19 








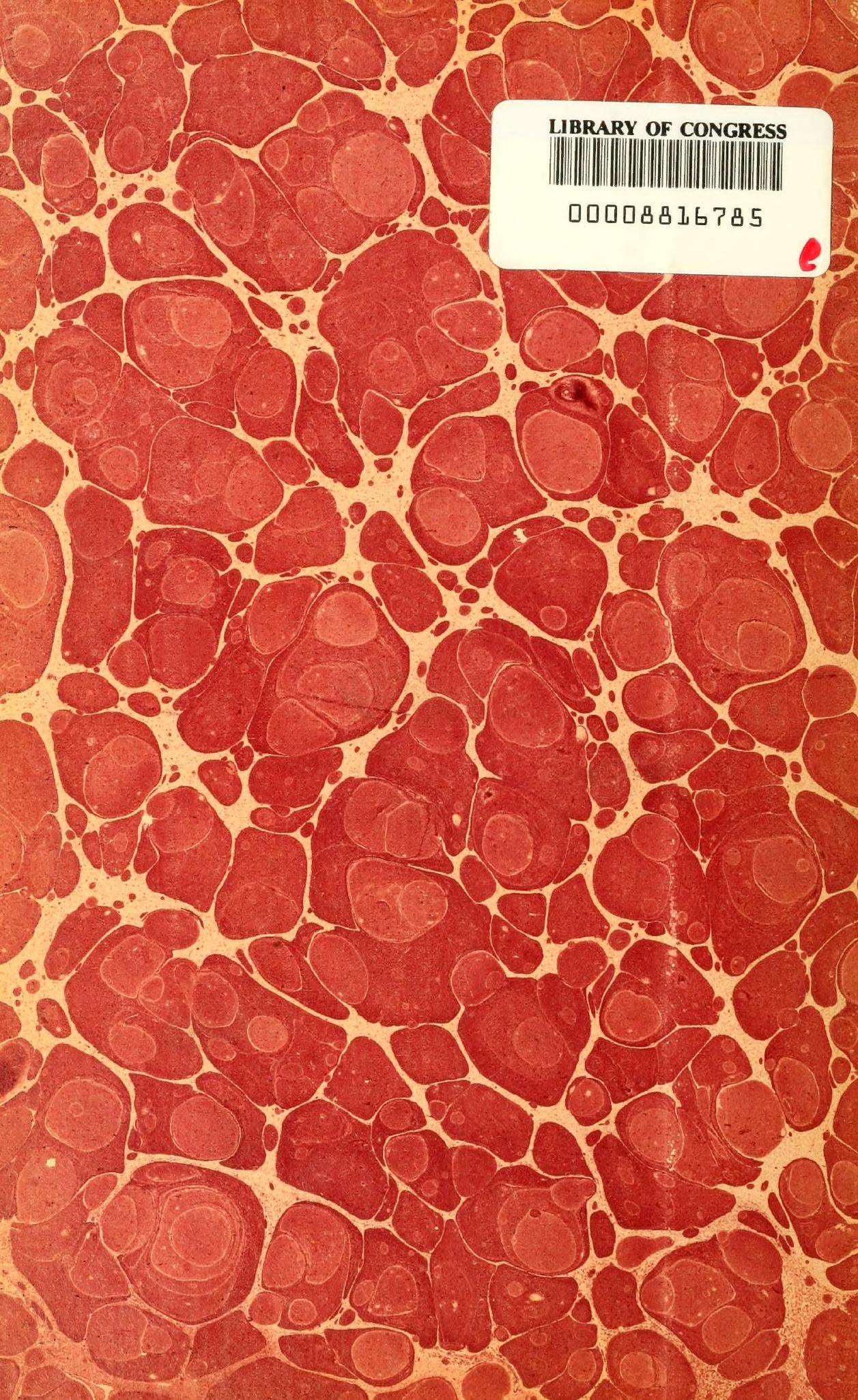

